\title{
Entrepreneur as an authentic leader: A study of small and medium sized enterprises in Pakistan
}

\author{
Taimoor Abid ${ }^{a}$, Mohsin Altaf ${ }^{a^{*}}$, Usman Yousaf ${ }^{b}$ and Mohammad Majid Mehmood Bagramc
}

${ }^{a}$ Department of Commerce University of Sargodha, Pakistan

${ }^{b}$ Lecturer, Quaid-i-Azam School of Management Sciences, Quaid-i-Azam University Islamabad, Pakistan

${ }^{c}$ Assistant Professor, Department of Business Administration, Allama Iqbal Open University, Islamabad, Pakistan

\section{A R T I C LE I N F O}

\section{Article history:}

Received March 29, 2012

Received in Revised form

June, 18, 2012

Accepted 1 August 2012

Available online

August 42012

Keywords:

Leadership

Entrepreneurs

SME

\begin{abstract}
The aim of this paper is to explore the authentic leadership styles of an entrepreneur and its impact on employee's commitment and satisfaction. By using the authentic leadership model, this study seeks to carry out a tentative test of the connection among employees' awareness of the business creator as an authentic leader and the employees' attitudes. Findings suggest that employee's opinion towards authentic leadership serves as the intoxicating analyst of employee job satisfaction and organizational commitment.
\end{abstract}

\section{Introduction}

Leadership is essentially from organizational sciences, which means how leader behaves in the organization, how to inspire their employees and their method of cooperation with conditions in the organization and how they can make major changes in organization (Bass, 1990). Some researchers comprise that sometimes leadership may not be important and sometimes leadership experts anticipate that leadership make a new design in the minds of supporters who try to occupy leadership roles.

Founders of new business enterprise (SME) have established and supported a new business enterprise, which not only builds vision and finance but also converts that vision and finance into successful and compatible business. Most researchers argued that organizational leaders play essential role. The founders of business are accountable for the availability of goods and services and for creation of new opportunities (Chandler \& Hanks, 1994).

* Corresponding author.

E-mail addresses: mohsin.iltaf@gmail.com (M. Iltaf) 
The term job satisfaction is the most commonly used variable in organizational behavior, which means the level of job satisfaction (Spector, 1997). The main factor for the decrease in employee production can be a low job satisfaction, which results as absenteeism (Martin \& Miller, 1986).

Organizational commitment is measured in various ways. The affective component of organizational commitment is associated with the emotional attachment and involvement of employees with the organization. The continuance component of organizational commitment means how likely an employee leaves from an organization. Finally, the normative component of organizational commitment is associated with feelings of employees to fulfill their obligations to connect with the organization and cohesion commitment refers to the individuals' attachment of affectivity of fund and emotions with the group (Kanter, 1968).

A suitable technique or sampling method restricts the results to arrange under the general heads. New investigational future research is necessary to evaluate the issues of the faculty of tracing effects to their causes and, on the other hand, the strength and the time period of distinguished relationships. The main point is that the new investigational future research diverts the attention toward the point that authentic leadership of business creator, not only impacts on the behavior of employee, but also it influences on the other hand on the routine acts of organization.

\section{Literature Review}

Positive psychology has come forward to cope with the increasing negativity in recent years. By watching, what is right with people, stressing and inculcating strengths rather than fixation of weaknesses (Seligman \& Csikszentmihalyi, 2000; Sheldonand King, 2001; Snyder \& Lopez, 2002).

It is advocated by Luthans (2002a, 2003b) that to field of organizational behavior this approach should be adopted and according to them authentic leadership is define as:

"It is a process that Is drawn from a highly developed organizational context and positive psychological capacities, as a result leaders and employees confront with greater self awareness and self regulated positive behaviors. The authentic leader is always optimistic, resilient, confident, hopeful, transparent, ethical and future oriented and furthermore he always prioritizes his subordinates also to be leaders (Luthans \& Avolio, 2003, p. 243)"”.

The concept of leadership can be started in the historical instructive literature (Henderson \& Hoy, 1983) but in the present scenario this theory is presented by Avolio and Luthans. In the present era motivated and skilled work force for necessary in global competition for growth and survival (Hamel, 2000; O'Reilly \& Pfeffer, 2000) and it also determines that actual and sustainable competitive advantage in the organization comes from the human side (Argyris,1993; Hitt \& Ireland, 2002; Pfeffer,1998). Further the environment in which entrepreneur of this era operates is very dynamic filled with economical changes and going concern for the business ethic make this concept of authentic leadership more critical.

An authentic leader must be capable of making achievements authentically by self acceptance, authentic actions and relationships and it goes beyond the leader's authenticity as a person and his/her relationships with his followers. Here the attention is concentrated towards self regulation and self awareness components of authentic leadership, instead of perspectives of positive moral and positive psychological states that are enhanced by authentic leadership.

As self awareness contributes a lot in authentic leadership linked with self reflection, authentic leaders confront with more clarity with the help of their emotions, values, motives, identity and goals. As self awareness is represented as a state where individual is concerned and employees have full and conscious attention towards themselves (Duval \& Wicklund, 1972). 
Brown et al. (2005) developed validation process where a ten-item instruments made by them for measuring ethical leadership perception. The ethical leadership scale (ELS) then were used to construct validation and the findings showed the association of ethical leadership, which was very positive and distinct from leaders honesty and influential dimensions of leadership of transformational nature (Bass \& Avolio, 2000). The connection of moral leadership is positive through trust and negative relationship with supervision of abuses nature.

Many articles have been written for many issues regarding business founders, which also includes differences between management and leaders (Robbins, 2002), cultivation trust of employees (Hiam, 2002) and growing business leadership (Hamm, 2002). In the same sense, little attention has started to be given to entrepreneur and small business owners as leaders. Here the concern is to highlight the ability of founder of the business as in communicating the clarified vision to his employees.

Ardichvili et al. (1998) presented many theories in entrepreneurial context in leadership style examination of Russian entrepreneurs. Furthermore, an emphasize was made by Baum at al. (1998) for exploring more about leadership, entrepreneurship and behavior of organization. A number of studies demonstrated impact of founder in the supply of financial and human capital (Gimeno et al. 1997).

Much of attention has given to founder/entrepreneur in the strategy entrepreneurship literature and organizational culture and a little attention is diverted towards industrialist as a leader who affects the attitude of work and rhetoric's of employees of him or her.

\section{Hypothesis}

H1 - There is a positive significant relationship among Authentic Leadership and employee Commitment.

H2 - There is a positive significant relationship among Authentic Leadership and job Satisfaction.

\section{Methodology}

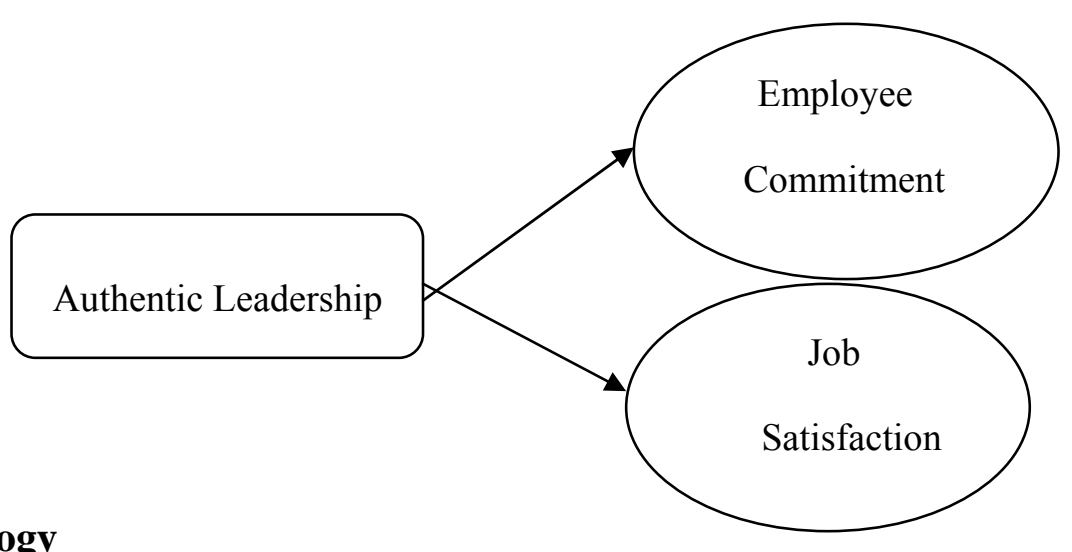

\subsection{Sample}

The survey is self administrated and paper-and-pencil method was used. Total no of 220 questionnaires were distributed among the employees of new small and Medium Enterprises. Out of 220 questionnaires, 10 questionnaires were discarded due to the reason of response biasness and incompleteness. 38.1\% were filled from public and $60 \%$ from private and $1.9 \%$ from semi government $(\mathrm{S} . \mathrm{D}=52) .27 .1 \%$ employees were on contract and $72.9 \%$ were on permanent posts (S.D=44.6). $71 \%$ employees fall in the category of $1-5$ year experience , $24.3 \%$ fall under $6-10$ year experience and 4.8 fall under the 11 or more year experience ( $\mathrm{S} . \mathrm{D}=76.8) .59 .5 \%$ employees were fall under the age of $20-30,36.2 \%$ were under $31-40$ and $4.3 \%$ under the age of 41 or more (S.D=57.8).. 


\subsection{Instruments}

The multifactor leadership questionnaire gives explanation about style of leadership. Responses are obtained on 5 point Likert scale .The OCS made by the Balfour and Wechsler (1996) to estimate the dimension of org. commitment by using 7 point Likert scale. The job satisfaction is measured by using 7 point Likert scale. The reliability of authentic leadership is .706, organizational commitment is .525 and job satisfaction is .616 .

\section{Results}

\subsection{Reliability}

\section{Table 1}

Reliability analyses

\begin{tabular}{llll}
\hline Variable & Authentic Leadership & Employee Commitment & Job Satisfaction \\
\hline Alpha Value & 0.706 & 0.525 & 0.616 \\
\hline
\end{tabular}

The Reliability value of the authentic leadership, employee commitment and job satisfaction is measured by Cronbech's Alpha. According to the results, The Alpha coefficient of authentic leadership is 0.706, Employee commitment is 0.525 and the Job Satisfaction is 0.616.

\subsection{Correlations}

Table 2

Correlation

\begin{tabular}{lllll}
\hline & & AL & EC & JS \\
\hline Authentic Leadership & Correlation Coefficient & 1.000 & $.483\left(^{* *}\right)$ & $.124\left(^{*}\right)$ \\
& Sig. (1-tailed) &. & .000 & .037 \\
& $\mathrm{~N}$ & 210 & 210 & 210 \\
\hline \multirow{2}{*}{ Employee Commitment } & Correlation Coefficient & $.483\left(^{* *}\right)$ & 1.000 & $.205\left(^{* *}\right)$ \\
& Sig. (1-tailed) & .000 &. & .001 \\
& $\mathrm{~N}$ & 210 & 210 & 210 \\
\hline \multirow{2}{*}{ Job Satisfaction } & Correlation Coefficient & $.124\left(^{*}\right)$ & $.205(* *)$ & 1.000 \\
& Sig. (1-tailed) & .037 & .001 &. \\
& $\mathrm{~N}$ & 210 & 210 & 210 \\
\hline ** Correlation is significant at the 0.01 level (1-tailed). & & & \\
\hline
\end{tabular}

* Correlation is significant at the 0.05 level (1-tailed).

The results of this Table 2 shows that there is a positive connection in authentic leadership and employee commitment $(\mathrm{r}=.483, \mathrm{p}<0.01)$ and also a positive relationship in authentic leadership and job satisfaction and $(\mathrm{r}=.124, \mathrm{p}<0.01)$ so $\mathrm{H} 1$ and $\mathrm{H} 2$ is acceptable.

\subsection{Linear Regression}

Table 3

Regression of Employee Commitment

\begin{tabular}{llllll}
\hline Variable & $\alpha$ & Std. error & Standardized coefficient & t-value & Sig \\
\hline Constant & 2.296 & .356 & & 6.443 & .000 \\
Authentic Leadership & 1.086 & .130 & .502 & 8.375 & .000 \\
$\mathrm{R}^{2}$ & .252 & & F-Statistic & 70.134 & \\
\hline
\end{tabular}

Dependent Variable= Employee Commitment 
$\mathrm{R}^{2}$ shows variance in employee commitment due to authentic leadership and that is $\left(\mathrm{R}^{2=} 0.252\right)$ that is significant. Value of $F$ is 70.134 that is significant and level of significance is $(p<0.01)$ that is totally acceptable, which tells that independent variable create variance in dependent variable. Value of standardized Beta of authentic leadership is 8.375 that is significant having value i.e $(\mathrm{p}<0.01)$, which shows a significant impact of leadership on employee commitment.

Table 4

Regression of Job Satisfaction

\begin{tabular}{llllll}
\hline Variable & A & Std. error & Standardized coefficient & t-value & Sig \\
\hline Constant & 5.409 & .325 & & 16.646 & .000 \\
Authentic Leadership & .225 & .118 & .131 & 1.906 & .045 \\
$\mathrm{R}^{2}$ & .017 & F-Statistic & 4.632 & & \\
\hline Dependent Variable=Job Satisfaction & & & &
\end{tabular}

Dependent Variable $=$ Job Satisfaction

$\mathrm{R}^{2}$ shows variance in job satisfaction due to authentic leadership and that is .017, which is significant. Value of $F$ is 4.632 that is significant and level of significance having value i.e. $(\mathrm{p}<.01)$ that is totally acceptable, which tells that independent variable create variance in dependent variable. Value of standardized Beta of authentic leadership is $(\beta=0.131)$ that is significant. This shows a significant impact of leadership on employee commitment.

\section{Conclusion}

According to the result of this research, we concluded that there is a positive relationship among leadership and employee commitment and job satisfaction. The important purpose is that Leadership builds a new relationship among leader behavior and employee attitudes. The results show that employees in new and small organizations sight their creator as an authentic leader and that it can have a positive impact on their occupational/job-related attitudes. Therefore, it can be said that leadership is a casual factor that influences on the employees behavior.

\section{Discussion}

The leadership gives modest concentration on how creator of business impacts on the decisions of their employees' behavior and job-related work as well as their performance. The result shows that leadership gives experiential help and the leaders have positive effect on the employees' job-related attitude. Furthermore, this research shows that organizational matters and deals affectively with the organizational commitment and employees' job satisfaction. The research established a positive connection between employees behavior and organizational profit such as production, security and performance. The further thing is that the process of leadership is not only affects behavior of employees but also affects on the performance. The process of leadership creates awareness among employees and plays important role in helping the continual absolute organization performance. That research not only made conclusion about performance but after that the future result or study give attention on that how leadership of head directly affects the performance and the durable goals of organization.

\section{References}

Argyris, C. (1993). Actionable Knowledge: Changing the Status Quo. San Francisco: Jossey-Bass. Ardichvili, A., Cardozo, R.N., \& Gasparishvili, A. (1998). Leadership styles and management practices of Russian entrepreneurs: implications for transferability of Western HRD interventions. Human Resource Development Quarterly, 9, 145-55.

Bass, B. M. (1990). Bass \& Stogdill's handbook of leadership: Theory, research and management applications. New York: Free Press. 
Bass, B. M., \& Avolio, B. J. (2000). Multifactor Leadership Questionnaire. Redwood City, CA: Mindgarden.

Brown, M. E., Treviño, L. K., \& Harrison, D. (2005). Ethical leadership: A social learning perspective for construct development and testing. Organizational Behavior and Human Decision Processes, 97,117-134.

Chandler, G.N., \& Hanks, S.H. (1994). Founder competence, the environment and venture performance. Entrepreneurship: Theory and Practice, 18(3), 77-90.

Duval, T. S., \& Wicklund, R. A. (1972). A Theory of Objective Self-Awareness. New York: Academic Press.

Gimeno, J., Folta, T.B., Cooper, A.C., \& Woo, C.Y. (1997). Survival of the fittest? Entrepreneurial human capital and the persistence of underperforming firms. Administrative Science Quarterly, 42, $750-783$

Hiam, A. (2002). The secret to entrepreneurial success. available at: www.Entrepreneur.com/article/0,4621,304726,00.html (accessed November 2002).

Hamm, J. (2002). Why entrepreneurs don't scale. Harvard Business Review, 110-115.

Hitt, M. A. and Ireland, R. D. (2002). The essence of strategic leadership: Managing human capital and social capital. Journal of Leadership and Organisation Studies, 9, 3-14.

Henderson, J. E., \& Hoy, W. K. (1983). Leader authenticity: The development and test of an operational measure. Educational and Psychological Research, 3(2), 63-75.

Hamel, G. (2000). Leading the Revolution. Harvard Business School Press, Boston, Massachusetts.

Kanter, R. (1968). Commitment and social organization: A study of commitment mechanisms in utopian communities. American Sociological Review, 33, 499-517.

Luthans, F., \& Avolio, B. (2003). Authentic leadership: A positive development approach. In K. S. Cameron, J. E. Dutton, \& R. E. Quinn (eds.), Positive organizational scholarship: 241-258. San Francisco: Berrett-Koehler.

Luthans, F. (2002a). The need for and meaning of positive organizational behavior. Journal of Organizational Behavior, 23, 695-706.

Luthans, F. (2002b). Positive organizational behavior: Developing and managing psychological strengths. Academy of Management Executive, 16(1), 57-72.

Martin, J. K., \& Miller, G. A. (1986). Job Satisfaction and Absenteeism: Organizational, Individual and Job-related Correlates. Work and Occupations, 13(1), 33-46.

O'Reilly, C.A., and J. Pfeffer (2000). Hidden Value: How Great Companies Achieve Extraordinary Results with Ordinary People. Boston: Harvard Business School Press.

Pfeffer J. (1998). The Human Equation: Building profits by putting people first. Boston, Harvard Business School Press.

Robbins, S.P. (2002). Organizational behaviors. (9th ed.). Upper Saddle River, NJ: Prentice Hall.

Seligman, M., \& Csikszentmihalyi, M. (2000). Positive psychology: An introduction. American Psychologist, 55, 5-14.

Sheldon, K.M., \& King, L. (2001). Why positive psychology is necessary. American Psychologist, 56, 216-217.

Snyder, C. R., \& Lopez, S. (eds.). 2002. Handbook of positive psychology. Oxford, UK: Oxford University Press.

Spector, P. E. (1997). Job satisfaction: Application, assessment, causes, and consequences. Thousand Oaks, CA: Sage. 